Article

\title{
Distributions and Losses of Logging Residues at Clear-Felled Areas during Extraction for Bioenergy: Comparing Dried- and Fresh-Stacked Method
}

\author{
Bengt Nilsson $^{\dagger}, *$, Daniel Nilsson ${ }^{\dagger}$ and Thomas Thörnqvist \\ Department of Forestry and Wood Technology, Linnaeus University, SE-351 95 Växjö, Sweden; \\ E-Mails: daniel.nilsson@Inu.se (D.N.); thomas.thornqvist@lnu.se (T.T.) \\ $\dagger$ These authors contributed equally to this work. \\ * Author to whom correspondence should be addressed; E-Mail: bengt.nilsson@lnu.se; \\ Tel.: +46-772-28-80-00; Fax: +46-470-70-85-40.
}

Academic Editors: Robert Harrison and Eric J. Jokela

Received: 9 July 2015 / Accepted: 13 November 2015 / Published: 20 November 2015

\begin{abstract}
It is well known that a large proportion of available logging residues intended for extraction will not reach the energy-conversion industry, because some are lost during transportation or left on the clear-felled area. However, there is little understanding of where logging residue losses occur in the supply chain. In this study, the distribution of logging residues for two methods (dried- and fresh-stacked method) to extract logging residues were studied in one clear-felled area. In addition, residue fractions were examined in a detailed comparison. Even though the fresh-stacked method left somewhat more logging residues at the clear-felled area, the differences are small between the methods. Approximately $30 \%$ of the total amount of logging residues was left behind between the harvester heaps, with an additional 10\%-15\% under these heaps and approximately $2 \%-3 \%$ beneath the windrows. The final product that was delivered to the energy-conversion industry was very similar, regardless of the extraction method used. The delivered chipped logging residues had moisture contents of $37 \%$ and $36 \%$ following fresh- and dried-stacked methods respectively, and in both cases the needle content in the processed logging residues was approximately $10 \%$. However, the total amount of fine fractions (needles and fines) was slightly higher following dried-stacking.
\end{abstract}


Keywords: forest fuel; storage; quality; needles; moisture content; Norway spruce

\section{Introduction}

Logging residues currently provide approximately $8 \mathrm{TWh}$ of energy annually for Sweden [1], and this amount could potentially be doubled [2,3]. This represents roughly $6 \%$ of the total amount of biofuels used in Sweden in 2012. Extraction of logging residues can be seen as a sustainable system since in today's levels neither threatens species [4], biodiversity [5], nutrient balance [5], nor have a negative exchange with respect to the input energy [6].

For energy purposes, logging residues can be gathered using several systems, the most common being comminution at landing [7]. This accounts for roughly $90 \%$ of all logging residues harvested in Sweden [2]. The extraction of logging residues starts with a fuel-adapted logging operation, meaning that the logging residues are placed in small harvester heaps, next to timber and pulpwood. The Swedish Forestry Agency currently recommends that logging residues should be kept in these harvester heaps over one summer, to facilitate drying and defoliation (needle fall-off) [5], because there is a need to increase the spread of the needles after the extraction of logging residues in order to redistribute nutrients. The logging residues should then be extracted from the forest and stacked in larger windrows at landings. These windrows are often covered with cardboard to prevent precipitation increasing the moisture content [8]. The logging residues are then stored until they are required at the designated energy-conversion plant. This method is often referred to as the dried-stacked method (dry-stacking).

However, an alternative known as fresh-stacked method (fresh-stacking) has been described by Nilsson et al. [9]. In this method, after the fuel-adapted logging operation, the logging residues are forwarded immediately after harvest to the landing, where drying and defoliation occur in windrows, instead of in small harvester heaps. In reality, it is even more difficult since dried-stacked logging residues often are more or less forwarded into a roadside pile earlier than is optimal. This due to, for example, faster regeneration of forest and logistical reasons (that the forwarders route is passing by the clear-felled area).

The moisture content of fresh logging residues is approximately $50 \%-60 \%$ on a fresh weight basis $[10,11]$. When the logging residues are left in small harvester heaps, the moisture content decreases; if stored for a whole summer, the moisture content can be lower than $20 \%-30 \%[12,13]$. However, several studies have shown that the moisture content decreases, even if the logging residues are stored in roadside windrows $[9,12,14,15]$. Logging residues stored over a summer, regardless of stacking method, will have a moisture content between $30 \%$ and $40 \%$ [9,16]. Logging residues located in the center parts of the windrows show lower moisture content than the outside parts of the windrow [17]. However, Nilsson et.al. [9] also reported that dried-stacked logging residues are generally somewhat drier than fresh-stacked logging residues, and concluded that differences among clear-felling areas and other variables affect the moisture content more than the extraction and storage method. The moisture content in logging residues is also affected by their particle size distribution, since the fine fractions absorb more moisture than the coarse fractions [18]. 
Dry mass losses due to handling are of particular importance and can be affected by diverse factors. For example, Lehtikangas [19] states that the size of the harvester heaps affects the amount of needle fall-off, which is expected to be considerably lower from large heaps than from smaller heaps. This is due to the greater compaction that occurs in a larger heap, when needles are accumulated in layers.

Some of the logging residues available within a stand will never reach the energy-conversion industry. Some will never even reach the harvester heaps, since some of the branches break off when the trees are felled and when branches are removed. Some of these losses due to the handling of the logging residues contribute to a more expensive fuel. According to Eriksson et al. [20], losses later in the supply chain imply a higher cost than early losses during the handling. With reference to a study by Mellström and Thörnlind 1981, Hakkila [10] reported that in certain cases up to $50 \%$ of logging residues cannot be gathered. Nurmi [21] showed that the $60 \%-80 \%$ of the logging residues can be extracted after harvest, depending on the effectiveness of the fuel adaptation. Peltola et al. [22] compared the measured dry weight of logging residues at an energy-conversion plant with the potential weight in the stand, using biomass models. They reported that at least a third of the logging residues remain at the clear-felled area, if stored in harvester heaps during the spring and summertime. Eriksson [23] showed that $24 \%$ to $34 \%$ of the total amount of available biomass was left at the clearfelled area when fresh logging residues were forwarded. The time of year and time between harvest and forwarding will also affect how much of the residues will be available for the energy-conversion industry. The longer the logging residues are left at the clear-felling area, the harder it becomes to gather all the material without contamination, due to ground vegetation having time to grow amongst the logging residues [24].

The defoliation (needle fall off) of logging residues depends on both how the material is handled during different operations, and the weather. In humid weather, the needles will stick to the wood chips and thus accompany the chips to the energy-conversion plant [25]. Wall and Hytönen [26] showed that dried-stacked extraction with the needles left on the clear-felled area does not reduce the long-term nutrient capital of the forest floor or the nutritional status of trees.

During storage in harvester heaps over a period of four months, Lehtikangas [19] found that between $24 \%$ and $42 \%$ of needles fall off. Filipsson and Nordén [25] reported that $18 \%-24 \%$ of the needles end up beneath the harvester heaps and $70 \%-77 \%$ in the roadside windrow. Filipsson and Nordén [25] also found that $0.6 \%-2.2 \%$ of the needles fell off during the normal loading of logging residues, and that active shaking during forwarding increased this proportion to $3.1 \%-5.5 \%$.

A number of studies performed in Sweden during the 1980s found that the composition of fresh logging residues from Norway spruce (Picea abies (L.) Karst) was 33\%-50\% wood, 20\%-30\% needles, $10 \%-20 \%$ bark, $5 \%-15 \%$ branches and 5\%-10\% of fines [27,28]. After storage Nurmi and Hillebrand [29] showed, in a study performed in southern Finland, a very low amount of needles, namely $2 \%$ in dried-stacked and $4 \%$ in fresh-stacked logging residues. Nilsson et al. [9] found that logging residues of Norway spruce in Southern Sweden have a needle content of $4 \%$ in dried-stacked and $8 \%$ in the fresh-stacked logging residues.

It has been previously thought that the traditional dried-stacked method leaves more needles at the clear-felling area than the fresh-stacked method. If the fresh-stacked method should be accepted, the opportunities for new technologies, reduced costs, shorter lead times, and increased withdrawal of logging residues from each clear-felled area would be possible. The aim of our study was to investigate 
and compare the traditional dried-stacked, and the fresh-stacked method from clear-felling until comminution at landing, regarding biomass losses (i), moisture content (ii), and fraction composition (iii). Another aim was to provide detailed information about the distribution of logging residues (iv) left in the clear-felled area and amounts of unusable logging residues that end up beneath the roadside windrow with the two systems.

\section{Materials and Methods}

\subsection{The Stand}

The study was conducted in 2013 in a stand dominated by 88 -year-old Norway spruce at Tommeshult, in the municipality of Emmaboda, approximately $40 \mathrm{~km}$ east of Växjö (Figure 1). The driving conditions at the clear-felling area were close to optimal for the machinery, in terms of absence of moist sites. There, none of the logging residues were needed for protecting the ground from rotting.

Visual examination indicated that there was less branch biomass than usual in a clear-felling area, because the crowns were hoisted. An experimental area of approximately one hectare was clear-felled; the site index was 26 (meaning dominant height in meters at 100 years of age). The clear-felled area was divided into two parts (Figure 1). The logging residues from the western and eastern part were gathered using the fresh- and dried-stacked methods, respectively. The fresh-stacked part was very flat and had an area of 0.43 hectare, with a tree species distribution of $13 \%$ Scots pine (Pinus sylvestris L.), $86 \%$ Norway spruce, and 1\% broadleaf, mainly birch (Betula spp.). The total harvested volume was $91 \mathrm{~m}^{3}$ solid roundwood under bark, from 279 stems. The dried-stacked part had somewhat more broken ground, covered 0.55 hectare, and the tree species distribution was $18 \%$ Scots pine and $82 \%$ Norway spruce. The total harvested roundwood volume was $111 \mathrm{~m}^{3}$ solid roundwood under bark, from 384 stems.

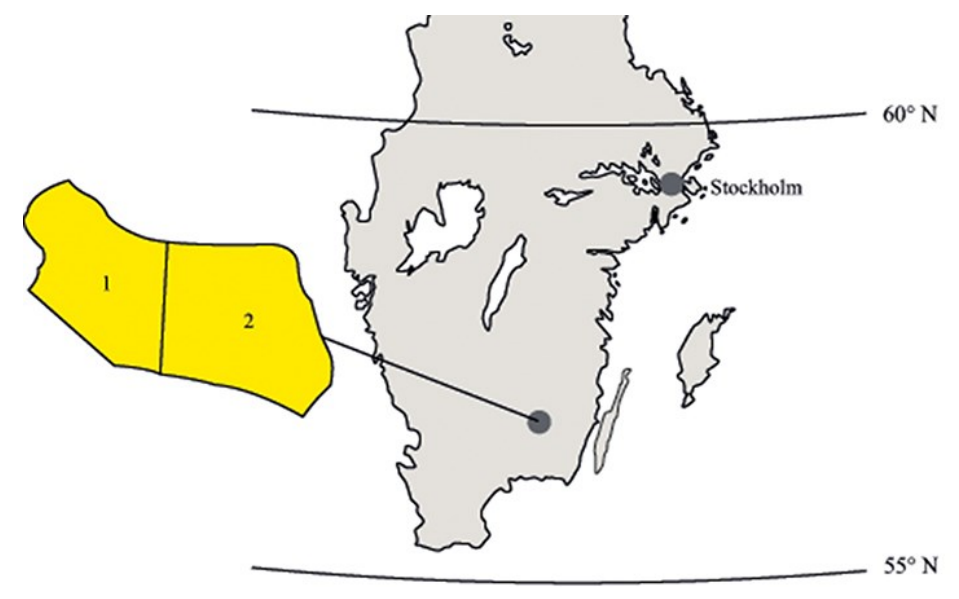

Figure 1. The location of the experimental clear-felled area in southern Sweden, divided into two parts used for the study. Logging residues were fresh-stacked in area 1 and dried-stacked in area 2. 


\subsection{Logging Operations}

Both parts of the stand were harvested by the same harvester operator in the middle of March 2013 (TR1) with a Rottne H20 final feller (Table 1). The logging operation was adapted for fuel extraction, and the harvester operator made approximately 30 harvester heaps per hectare. The logging residues from the 13 fresh-stacked harvester heaps were forwarded at the beginning of April 2013 (TR2) with a Timberjack 1410 B, covering $7.7 \%$ of the clear-felled area. The logging residues were collected and placed in a fresh-stacked windrow (approximately $20 \mathrm{~m}$ long, $5 \mathrm{~m}$ wide and $4 \mathrm{~m}$ at its highest point) at the roadside. The delay in forwarding was caused by heavy snowfall the day after final felling. Therefore, these logging residues had some time to dry during the time it took for the snow to melt, and the initial moisture content was lower than expected for fresh logging residues.

Table 1. Time references (TR1-TR5) for the different operations during the procurement of the logging residues (" $\mathrm{x}$ " means no activity).

\begin{tabular}{lccc}
\hline Time Reference & Time & Fresh-Stacked & Dried-Stacked \\
\hline TR1 & Mar 2013 & Harvested & Harvested \\
TR2 & Apr 2013 & Forwarded and stacked & x \\
TR3 & Sept 2013 & x & Forwarded and stacked \\
TR4 & Sept 2013 & Covered with cardboard & Covered with cardboard \\
TR5 & Nov 2013 & Comminution & Comminution \\
\hline
\end{tabular}

The logging residues from the 17 dried-stacked harvester heaps were stored in the harvester heaps (approximately $5 \mathrm{~m}$ in diameter and $1.5 \mathrm{~m}$ high), covering $7.2 \%$ of the clear-felled area. The dried-stacked harvester heaps were placed on permeable tarpaulins to trap all fall-off from the logging residues. The logging residues were then forwarded (by a John Deere 1110D) in the middle of September 2013 (TR3), and during the forwarding, were stacked in a roadside windrow, approximately $25 \mathrm{~m}$ long, $5 \mathrm{~m}$ wide and $4 \mathrm{~m}$ high at its highest point.

When the dried-stacked logging residues had been forwarded, both (the dried- and fresh-stacked) roadside windrows were covered with cardboard to avoid re-moistening after the summer drying (TR4). To allow gathering of most of the fines and needles, the roadside windrows were placed on plastic sheets, arranged in order to allow water from precipitation to drain away. Both windrows had similar locations along the roadside, with similar exposure to sunlight, wind and precipitation. The experiment ended in mid-November 2013 (TR5), when both windrows were comminuted separately by a Jenz Hem 582 chipper, mounted on a Volvo truck.

\subsection{Sampling Methodology}

Fifteen sample plots between the harvester heaps were selected in each of the fresh- and dried-stacked parts of the clear-felled area, using a random number generator in Microsoft Office Excel. Each plot was then marked on a map of the clear-felled area and GPS coordinates were used to find each sample plot. Each plot was identified as the center point of a $5 \mathrm{~m}^{2}$ sample plot (Figure 2). If a sample plot overlapped an obstacle, for example a harvester heap or another sample plot, the center point was moved in $3 \mathrm{~m}$ intervals to the north, until the whole sample plot was free of the obstacle. All 
logging residues were collected from the entire sample plot. In the dried-stacking site, the sample plots were carefully marked, so that after forwarding, it would be possible to again collect new material that had fallen off with the intention to quantify losses occurred during forwarding. The moisture contents of the logging residues were determined by weighing before and after oven drying at $105 \pm 2{ }^{\circ} \mathrm{C}$ for $24 \mathrm{~h}[30]$.

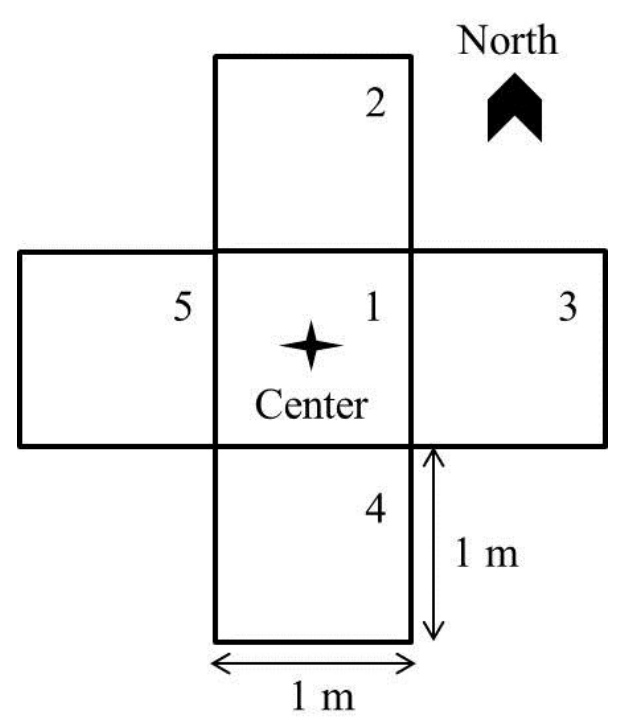

Figure 2. Sample plot pattern used for gathering the logging residues in the clear-felled area and under the harvester heaps.

After forwarding the fresh-stacked logging residues in April (TR2), one of the five $1 \mathrm{~m}^{2}$ sample plots (Figure 2) was selected at random under each harvester heap; all remaining residues were collected as previously described, and oven-dried to determine their moisture contents. The amount of dried-stacked logging residues left under the harvester heaps was determined in the same way after forwarding in September (TR3).

In November (TR5), when the logging residues had been chipped, the total area of the windrow had increased due to the chip truck's handling of the residues during comminuting, by approximately $1 \mathrm{~m}$ width of the windrow. The logging residues on this increased surface, in terms of dry mass per unit surface area and fraction composition, were estimated to be similar to the logging residues left under the windrow. After chipping, the area under the windrow (including the increased surface area) was divided into a grid of $1 \mathrm{~m}^{2}$ squares. From each windrow, ten of the squares were randomly selected and all logging residues were collected to determine their moisture content and dry mass.

Since the amount of logging residues varied greatly between the investigated sample plots under the windrow, a boxplot was constructed in SPSS (www.ibm.com) to see if some of the sample plots where outliers and should be excluded from the calculations. 


\subsection{Moisture Content and Fraction Composition}

The moisture content and fraction composition of chipped logging residues were analyzed on four sampling occasions. The first occasion (A) was while forwarding the fresh logging residues in April (TR2), the second (B) while forwarding the dried logging residues in September (TR3), the third (C) after chipping the fresh-stacked windrow in November (TR5), and the fourth (D) after chipping the dried-stacked windrow in November (TR5). On the first two occasions, A and B, the operator of the forwarder was asked to fill a covered car trailer with unchipped logging residues. These logging residues were transported directly to the nearest wood chipper for processing and samples were taken for moisture content and fraction composition determinations. When the logging residues were chipped in November (TR5), samples were taken after the chip truck had unloaded the container at the energy-conversion plant. The sampling method on all four occasions was as follows: five bucket-samples $(10 \mathrm{~L}$ each) were taken from different positions in the pile of chipped residues. The total volume of $50 \mathrm{~L}$ was then placed on a tarpaulin and mixed well before removing five $2 \mathrm{~L}$ samples. This procedure was repeated six times for each pile of residues. Thus, in total, 30 samples were gathered on each occasion. After collection, all samples were weighed and oven-dried, in order to calculate the moisture content.

When dried, all 30 samples were bulked into a larger sample. From this large sample, 15 smaller samples of approximately $0.3 \mathrm{~L}$ were gathered using a sampling board. The sampling board contained 15 holes, each $120 \mathrm{~mm}$ in diameter and equipped with a trapdoor for automatic sampling. Of these samples, five were randomly selected and separated into three different fractions. The fractionation was performed with a chip classifier using screen boxes with mesh sizes of 45, 13, 7 and $3 \mathrm{~mm}$. From the screen boxes and the fines pan, three fractions were manually separated: (1) coarse material (wood, branches, and bark) over $3 \mathrm{~mm}$ in diameter; (2) fines less than $3 \mathrm{~mm}$ in diameter, and (3) needles. This was repeated on all four sampling occasions.

\subsection{Weather Conditions}

In order to describe the climatic conditions during the experiment, weather data were collected from SMHI (the Swedish Meteorological and Hydrological Institute) (Figures 3 and 4). The weather data used for this study were gathered from weather stations located within $10 \mathrm{~km}$ of the clear-felled area. The weather data show monthly precipitation and mean temperatures during the study period, as well as normal average values, based on data for the 30-year period spanning from 1961-1990. Annual average precipitation is approximately $600 \mathrm{~mm}$. During the study (March to November), the periodic average precipitation was $487 \mathrm{~mm}$. The total precipitation during the study period from March to November 2013 was slightly lower at $421 \mathrm{~mm}$. 
Precipitation (mm) in Tommeshult, 2013

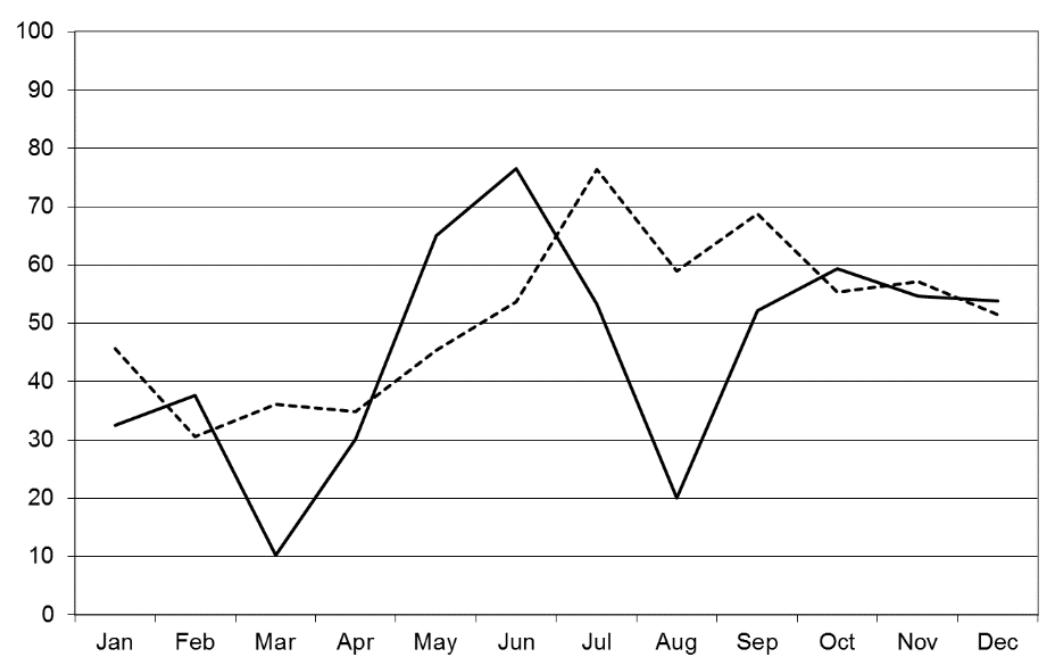

Figure 3. Monthly precipitation in $\mathrm{mm}$ at the Swedish Meteorological and Hydrological Institute (SMHI) weather stations over the study period (-). The 30-year average values for the same period (1961-1990; -----) are also shown.

Temperature $\left({ }^{\circ} \mathrm{C}\right)$ in Tommeshult, 2013

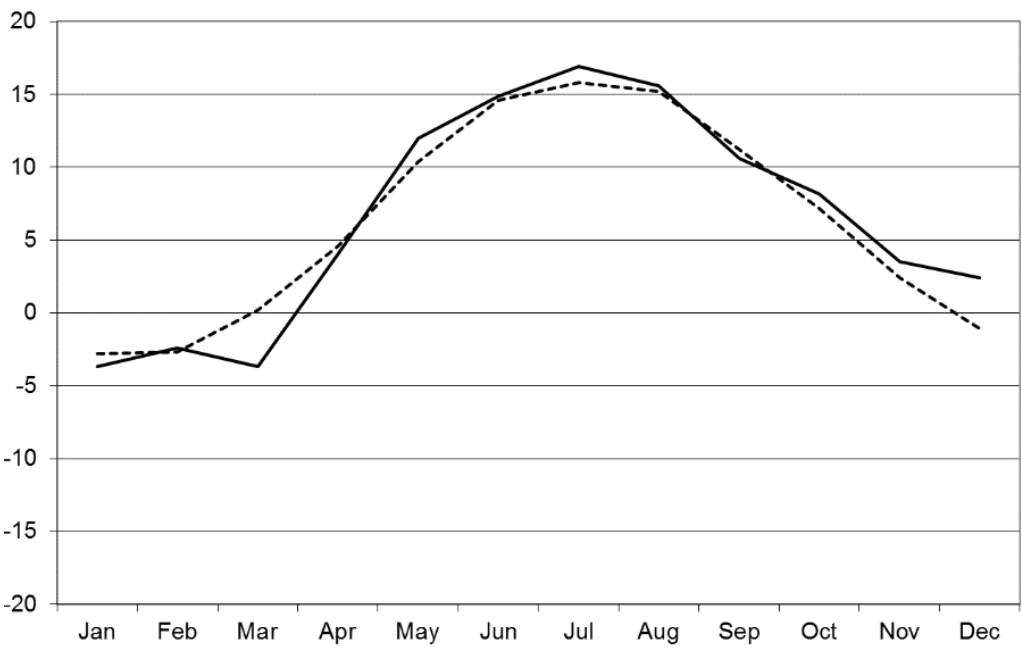

Figure 4. Average monthly temperature in ${ }^{\circ} \mathrm{C}$ at the SMHI weather stations over the study period (-). The 30-year average values for the same period (1961-1990; -----) are also shown.

\section{Results}

\subsection{Moisture Content}

When forwarded, the fresh-stacked (TR2) logging residues had a moisture content of $40.2 \%$. The logging residues handled by the dried-stacked method had an initial moisture content of $32.4 \%$ when forwarded into a roadside windrow in September (TR3). When chipped in November (TR5), the moisture content had increased and was almost identical: $36.9 \%$ for fresh-stacked and $36.4 \%$ for dried-stacked logging residues, respectively. 


\subsection{Distribution and Yield of Logging Residues}

The dry mass of logging residues delivered to the energy-conversion plant (TR5) was determined via weighing and measurement of the moisture content. The obtained value was then calculated to apply for dry mass from one hectare clear-felling. The total potential of logging residues was determined by the delivered dry mass together with the result from the sample plots between the heaps, beneath the heaps, and beneath the windrow. From the clear-felled area handled using the freshstacked method, the potential logging residue was calculated to be 39 ton dry mass (DM) ha ${ }^{-1}$, while the actual delivered amount was 22 ton $\mathrm{DM} \mathrm{ha}{ }^{-1}$. For the clear-felled area handled with the driedstacked method, the total potential was 38 ton $\mathrm{DM} \mathrm{ha}^{-1}$ and the amount of material delivered was 20 ton $\mathrm{DM} \mathrm{ha} \mathrm{h}^{-1}$. This equates to total dry mass losses of $44 \%$ (17 ton $\mathrm{DM} \mathrm{ha}^{-1}$ ) for the fresh-stacked method and 48\% (21 ton $\mathrm{DM} \mathrm{ha}^{-1}$ ) for the dried-stacked method. The distribution of the logging residues (Table 2) across the clear-felled area indicated that approximately $30 \%$ of the logging residues were located between the harvester heaps, regardless of which method was used.

Table 2. The distribution of $\%$ dry matter on the clear-felling area and at the landing when using the two handling methods. The results are also shown in $\mathrm{kg}$ dry mass (DM) $\mathrm{m}^{-2}$ (actual result from the sample plots) and ton $\mathrm{DM} \mathrm{ha}^{-1}$ of clear-felled area (considering the clear-felled areas actual appearance regarding surface area of harvester heaps, etc.). Data are means and standard deviations (s). The delivered amount of logging residues as well as the logging residues that ended up beneath the chip truck is total measurements.

\begin{tabular}{|c|c|c|c|c|c|c|c|c|}
\hline & \multicolumn{4}{|c|}{ Distribution of Fresh-Stacked } & \multicolumn{4}{|c|}{ Distribution of Dried-Stacked } \\
\hline & $\operatorname{kg~DM~m} \mathrm{m}^{-2}$ & $\mathbf{s}$ & ton DM ha $\mathbf{h}^{-1}$ & $\%$ & $\operatorname{kg~DM~m}^{-2}$ & $\mathbf{s}$ & ton DM ha $\mathbf{h a}^{-1}$ & $\%$ \\
\hline Between heaps & 1.4 & 1.0 & 13.0 & 32.6 & 1.3 & 1.0 & 11.7 & 30.5 \\
\hline Beneath heaps & 4.8 & 1.9 & 3.7 & 9.3 & 7.0 & 2.7 & 5.0 & 13.1 \\
\hline Beneath windrow & 3.8 & 1.8 & 0.4 & 2.4 & 4.7 & 3.2 & 1.0 & 4.5 \\
\hline Beneath chip truck & & & 0.0 & 0.1 & & & 0.0 & 0.1 \\
\hline Delivered & & & 22.1 & 55.6 & & & 20.0 & 51.8 \\
\hline
\end{tabular}

Following fresh- and dried-stacking, an additional $9 \%$ and $13 \%$ of the total amount of logging residues were found beneath the harvester heaps, respectively. Notably, the residues beneath the harvester heaps were concentrated on $7 \%-8 \%$ of the total clear-felled area. Beneath the fresh- and dried-stacked windrows, $2 \%$ and $5 \%$ of the logging residues were found, respectively. The amount of logging residues spilled beneath the chip truck was negligible (approximately 20-30 kg DM, regardless of extraction method).

\subsection{Needle Distribution}

The total amounts of residues recorded in this study indicate that the total amount of needles present in the fresh- and dry-stacking areas were estimated to 5.8 and 5.5 ton $\mathrm{DM} \mathrm{ha}{ }^{-1}$, respectively. The results show that despite optimal conditions for needle fall-off during the dry summer and long storage time in small harvester heaps, about $33 \%$ of the needles in the dried-stacked logging residues and $39 \%$ of the fresh-stacked residues ended up at the energy-conversion plant. 
From the results of this study, we cannot conclude exactly how the remaining needles were distributed at the clear-felled area, since it is based on estimation, based on the total potential of the dry mass logging residues and the fraction composition. The results should therefore be viewed from a larger perspective where the distribution in percentages gives the most accurate description. Using the unit $\mathrm{kg} \mathrm{DM} \mathrm{m}^{-2}$, for example, could be misleading since the estimation gives $4.3 \mathrm{~kg} \mathrm{DM} \mathrm{m}^{-2}$ of needles under the windrow while the total amount of logging residues there was $3.8 \mathrm{~kg} \mathrm{DM} \mathrm{m}^{-2}$. This is, in reality, equivalent to an error estimation of only $120 \mathrm{~kg} \mathrm{DM} \mathrm{ha}^{-1}$ of the total amount of needles (5.8 ton $\mathrm{DM} \mathrm{ha}^{-1}$ ) at the cleared-felled area. However, from the distribution of logging residues and their fraction composition, it can be estimated that the needles would be distributed as shown in Table 3 . Roughly $30 \%$ of the needles were distributed between the harvester heaps regardless of extraction method. The main difference between the two methods was the amount of needles found beneath the harvester heaps and beneath the roadside windrow. The fresh-stacked method yielded a higher needle concentration beneath the windrow (19\%), whilst the dried-stacked method yielded a higher needle concentration beneath the harvester heaps $(25 \%)$.

Table 3. The estimated distribution of $\%$ needles on the clear-felled area using the two handling methods. The results are also shown in $\mathrm{kg} \mathrm{DM} \mathrm{m}^{-2}$ and ton $\mathrm{DM} \mathrm{ha}^{-1}$ of clear-felled area. The delivered amount of needles as well as the needles that ended up beneath the chip truck equates the total measurements.

\begin{tabular}{|c|c|c|c|c|c|c|}
\hline & \multicolumn{3}{|c|}{ Fresh-Stacked } & \multicolumn{3}{|c|}{ Dried-Stacked } \\
\hline & $\mathrm{kg} \mathrm{DM} \mathrm{m}^{-2}$ & ton DM ha $\mathbf{h a}^{-1}$ & $\%$ & kg DM m ${ }^{-2}$ & ton DM ha ${ }^{-1}$ & $\%$ \\
\hline Between heaps & 0.2 & 1.9 & 32.6 & 0.2 & 1.7 & 30.9 \\
\hline Beneath heaps & 0.7 & 0.5 & 9.3 & 1.9 & 1.4 & 25.3 \\
\hline Beneath windrow & 4.3 & 1.1 & 19.3 & 2.2 & 0.6 & 10.2 \\
\hline Beneath chip truck & & 0.0 & 0.0 & & 0.0 & 0.01 \\
\hline Delivered & & 2.2 & 38.7 & & 1.8 & 33.4 \\
\hline
\end{tabular}

\subsection{Fraction Composition}

The fraction composition of coarse material in the logging residues is very similar regardless of the time of measurement during the procurement. The difference in fraction composition is found in the amounts of fines and needles (Table 4). 
Table 4. The mean content (\%) and standard deviation (s) of indicated fractions in the four types of samples of logging residues: A, fresh material in April (TR2); B, the dried-stacked material at the time of forwarding to the roadside windrow in September (TR3); C and D, the fresh- and dried-stacked material when delivered after chipping in November (TR5), respectively.

\begin{tabular}{lcccccccc}
\hline & \multicolumn{2}{c}{ A } & \multicolumn{2}{c}{ B } & \multicolumn{2}{c}{} & \multicolumn{1}{c}{ D } \\
& Distr. (\%) & S & Distr. (\%) & s & Distr. (\%) & s & Distr. (\%) & s \\
\hline Coarse $>$ 3mm & 78.0 & 9.1 & 70.1 & 4.4 & 77.7 & 10.2 & 75.2 & 8.3 \\
Fines & 7.5 & 4.1 & 18.5 & 4.8 & 12.2 & 8.4 & 15.6 & 6.7 \\
Needles & 14.5 & 5.2 & 11.4 & 1.8 & 10.1 & 2.0 & 9.2 & 1.6 \\
\hline
\end{tabular}

\section{Discussion}

\subsection{Moisture Content}

When chipped in November (TR5), the moisture content was almost identical, and between $30 \%$ and $40 \%$ for both dried-stacked and fresh-stacked logging residues. This corresponds well with findings by $[9,16]$ and corresponds well with the needs of the energy-conversion industry.

The plastic sheets beneath the windrows could have affected the results, for example by changing the microclimate around the residues from the usual conditions when in direct contact with the ground. The most obvious associated risk was accumulation of water, but this was prevented by the arrangement of the plastic sheets. After chipping, it was clear that most of the water had been able to drain away from the plastic beneath the roadside windrows. The logging residues had also pierced the plastic in several places, allowing additional water to drain away. Therefore, the plastic is believed to have had minor effects on the results.

\subsection{Distribution and Yield of Logging Residues}

The similarity in the results of the distribution of logging residues left at the clear-felling area was expected because the logging operation until forwarding was identical, so the amount of logging residues that fell off during the harvesting operation should have been very similar. A slightly higher proportion of logging residues is left beneath the harvester heaps after dried-stacking, compared to the amount left with fresh-stacking, which can be explained by needles and other fines falling off the branches during storage. However, recommendations from the Swedish Forest Agency [5] to leave 20\% of logging residues in clear-felling areas could clearly be satisfied, regardless of the method used for gathering the logging residues.

General thoughts by entrepreneurs and the industry state that the fresh-stacked method should yield more material left beneath the windrow, since the potential for fall-off should have been greater when handling the fresh-stacked residues with a higher amount of needles. Finding more material beneath the dried-stacked windrow was therefore unexpected. A possible explanation for the discrepancy is that the summer drought and re-humidification in the harvester heaps at the clear-felling area made the logging residues more brittle, resulting in more needles, bark and small branches breaking off during 
handling operations. This would imply that the fresh-stacked logging residues are more stable, as higher proportions of the finer fractions appeared to stay on the branches.

There were large differences in amounts of logging residues among the sample plots beneath the windrows, resulting in large standard deviations that obscured any potentially significant differences between the methods. The strongest deviations were among samples from beneath the dried-stacked roadside windrow, one of which amounted to $26 \mathrm{~kg}$, while the rest of the sample plots yielded $0.1-9 \mathrm{~kg}$ of logging residues. This variability reflects the uneven ground; the plot yielding the extremely high sample was in a pit where the operator of the chipper truck was unable to gather all the logging residues. A boxplot, constructed in SPSS (www.ibm.com), confirmed that the sample plot beneath the windrow with $26 \mathrm{~kg} \mathrm{~m}^{-2}$ was an outlier and was therefore excluded from the calculations. The unevenness of the ground might also have affected the differences in residue amounts between plots beneath the windrow and beneath the harvester heaps. The amount of logging residues spilled beneath the chip truck was very low and was due to the design of the chipper feed, which incorporated a large feeding table.

As a field trial of this kind requires significant resources, this study was limited to one clear-felled area and the focus was to carefully determine the amounts and distribution of logging residues. That the results are derived from just one clear-felling should be kept in mind when interpreting the results. The potential of logging residues from other clear-fellings can certainly vary. However, once the harvest is complete, the assessment is that the distribution of logging residues spread in a similar fashion. The technique and skill among operators of both the harvester and the forwarder may influence the distribution at the clear-felled area and the possible withdrawal, equally as the total potential extraction of logging residues.

\subsection{Distribution of Needles}

The needle fall-off beneath the harvester heaps were lower than previously stated, despite leaving the residues in harvester heaps to promote high needle fall off with the dried-stacked method. This confirms the premise of Filipsson and Nordén [25], and also Nilsson et al. [9], that attempts to shed the needles on the clear-felling area often do not succeed. Despite having optimum drying conditions, with a dry summer and a long storage period in small harvester heaps, most of the needles did not fall off in the clear-felled area. Relatively large harvester heaps may also have contributed to the fact that the needles did not fall off during the summer drying of the dried-stacked logging residues at the clear-felled area, as was demonstrated by Lehtikangas [19]. Both methods in the end yielded a fuel with low needle content, as required by the energy-conversion industry. However, the possibility to actively leave most of the needles at the clear-felled area so that it may benefit the next generation of the forest is questionable.

Regardless of the method, approximately $30 \%-40 \%$ of the needles available in the stand were delivered to the energy-conversion plant. The windrow is not considered to be part of the clear-felled area, as it is often in the vicinity of a roadside ditch and hence close to streams. In summary, we estimated that one third of the needles end up at the energy-conversion site, one third is spread at the clear-felled area between the harvester heaps, and the last third is concentrated beneath the harvester heaps and the roadside windrow. 


\subsection{Fraction Composition}

The proportion of needles found in the fresh logging residues (TR2) is considerably lower than the proportions $(20 \%-30 \%)$ reported in earlier studies in Sweden, for example, Thörnqvist [28] and Flinkman et al. [27]. This may have been partly due to the hoisted crowns in the study stand. Additional drying of the logging residues, during the delay in forwarding of the fresh residues, may also have reduced the needle content. However, the needles were seemingly firmly attached to the branches during forwarding, so the delay probably had little effect on the needle content of material reaching the windrow. Another factor that might have affected the amount of needles was the distribution of the three tree species. Contributions from either broadleaf trees or Scots pine would have reduced the total needle content.

Notably, the dried-stacked logging residue had a higher proportion of fines, but the proportion of the most valuable coarse fraction was very similar with both extraction methods. In fact, the results indicate that dry-stacking resulted in a higher total of needles and other fines content than fresh-stacking. This may be partly due to the dried-stacked residues being more brittle, leading to greater increases in fine contents during extraction.

\section{Conclusions}

Fresh- and dry-stacking extraction methods resulted in the delivery of very similar proportions (56\% and $52 \%$, respectively) of the logging residues to the energy-conversion plant in November, with nearly identical moisture contents (37\% and 36\%, respectively). Furthermore, for both methods approximately $30 \%$ of the total residues were found between the harvester heaps, approximately $10 \%-15 \%$ beneath the harvester heaps and $2 \%-5 \%$ beneath the windrows. This study also showed that the distribution of logging residues was well spread over the clear-felled area. Therefore, both methods satisfy recommendations of the Swedish Forest Agency to leave 20\% of the logging residues spread on clear-felled areas, in order to prevent nutrient losses from the system. However, neither of the methods left the needles evenly spread because the needles that fell off beneath the harvester heaps were concentrated on $7 \%-8 \%$ of the total clear-felled area. Even though weather conditions during this study were favorable for needle fall off, a substantial proportion of needles reached the energy-conversion plant. This confirms that attempts to shed the needles on the clear-felling area using the dried-stacked method often do not have the desired effect.

Notably, the final product delivered to the energy-conversion industry was very similar, regardless of the method. Generally, the results are consistent with findings by Nilsson et al. [9], that logging residues stored over one summer consist of 5\%-10\% needles and have a moisture content of approximately $30 \%-40 \%$, regardless of whether they are fresh- or dried-stacked. In practice, logging residues delivered to the energy-conversion plant are often neither fresh- nor dried-stacked, but something in between, due to that forwarding occurs when practically and logistically appropriate.

The results indicate that from a logistical perspective, it might be advantageous to forward logging residues directly after roundwood harvests, using the same forwarders while they are still on-site. This might be particularly suitable where the clear-felled areas are generally small with a high concentration of logging residues and machinery relocation costs are high. Additional studies are needed to 
investigate the needle content in fresh logging residues in southern Sweden, and to clarify more comprehensively the distribution of needles at clear-felled sites after logging residue extraction. Repeated studies at more clear-felled areas would be interesting to see if the results are generalizable to other areas, as well as to verify the influence of the operators skill and technique during logging and forwarding operations, of the distribution and withdrawal of logging residues. Detailed comparison of nutrient offtake with the different storage and extraction methods would also be valuable.

\section{Acknowledgments}

The authors thank the south Swedish forest owner organization "Södra" and their entrepreneurs and the energy-conversion industry "Lessebo Fjärrvärme" for enabling this study. The authors also thank the Swedish Agency for Economics and Regional Growth for their financial support through the research program "Energi från Skogen" (Energy from the forest). Finally, thanks are due to the forest owner Kennert Karlsson for supporting the study by providing the clear-felling site in Tomeshult and Gunnar Eliasson for helping with the laboratory work.

\section{Author Contributions}

Bengt Nilsson, Daniel Nilsson and Thomas Thörnqvist conceived and designed the experiments; Bengt Nilsson, Daniel Nilsson and Thomas Thörnqvist performed the experiments; Bengt Nilsson and Daniel Nilsson analyzed the data and wrote the paper.

\section{Conflicts of Interest}

The authors declare no conflict of interest. The founding sponsors had no role in the design of the study, in the collection, analyses, or interpretation of data; in the writing of the manuscript, or in the decision to publish the results.

\section{References}

1. De Jong, J.; Akselsson, C.; Berglund, H.; Egnell, G.; Gerhardt, K.; Lönnberg, L.; Olsson, B.; von Stedingk, H. Konsekvenser av ett Ökat Uttag av Skogsbränsle. En Syntes Från Energimyndighetens Bränsleprogram 2007-2011. (Consequences of an Increased Forest Fuel Withdrawal. Composite Report from the Swedish Energy Agency's $R$ \& $D$ Programme 2007-2011); Report No. 8; Swedish Energy Agency: Eskilstuna, Sweden, 2012; p. 228. (In Swedish). Available online: http://www.slu.se/Global/externwebben/centrumbildningarprojekt/centrum-for-biologisk-mangfald/Dokument/publikationer-cbm/2013-konsekvanser-av-okatuttag-skogsbransle.pdf (accessed on 4 May 2015).

2. Routa, J.; Asikainen, A.; Björheden, R.; Laitila, J.; Röser, D. Forest energy procurement: State of the art in Finland and Sweden. WIREs Energy Environ. 2013, 2, 602-613.

3. Helmisaari, H.; Kaarakka, L.; Olsson, B. Increased utilization of different tree parts for energy purposes in the Nordic countries. Scand. J. For. Res. 2014, 29, 312-322. 
4. Dahlberg, A.; Thor, G.; Allmér, J.; Jonsell, M.; Jonsson, M.; Ranius, T. Modelled impact of Norway spruce logging residue extraction on biodiversity in Sweden. Can. J. For. Res. 2011, 41, 1220-1232.

5. Hjerpe, K.; Anderson, S.; Eriksson, H.; Lomander, A.; Samuelsson, H.; Stendahl, J.; Wallstedt, A. Rekommendationer vid Uttag av Avverkningsrester och Askåterföring (Recommendations for the Extraction of Forest Fuel and Compensation Fertilising); Meddelande; Report No. 2; Skogsstyrelsen, Skogsstyrelsens Förlag: Jönköping, Sweden, 2008; p. 33. (In Swedish). Available online: http://shop.skogsstyrelsen.se/sv/publikationer/meddelanden/rekommendationer-vid-uttagav-avverkningsrester-och-askaterforin.html (accessed on 4 May 2015).

6. Börjesson, P. Energy analysis of biomass production and transportation. Biomass Bioenergy 1996, 11, 305-318.

7. Thorsén, Å.; Björheden, R.; Eliasson, L. Efficient Forest Fuel Supply Systems-Composite Report from a Four Year R \& D Programme 2007-2010; Skogforsk: Uppsala, Sweden, 2011. Available online: http://www.skogforsk.se/contentassets/13f65170eaa5477b842f4d2f3de7b282/ess-2007-2010eng-low.pdf (accessed on 4 May 2015).

8. Pettersson, M.; Nordfjell, T. Fuel quality changes during seasonal storage of compacted logging residues and young trees. Biomass Bioenergy 2007, 31, 782-792.

9. Nilsson, B.; Blom, Å.; Thörnqvist, T. The influence of two different handling methods on the moisture content and composition of logging residues. Biomass Bioenergy 2013, 52, 34-42.

10. Hakkila, P. Utilization of Residual Forest Biomass; Springer Series in Wood Science: Berlin, Germany; Heidelberg, Germany; New York, NY, USA, 1989.

11. Andersson, G.; Askiainen, A.; Björheden, R.; Hall, P.W.; Hudson, J.B.; Jirjis, R.; Mead, J.; Nurmi, J.; Weetman, G.F. Production of forest energy. In Bioenergy from Sustainable Forestry-Guiding Principles and Practice; Richardsson, J., Björheden, R., Hakkila, P., Lowe, A.T., Smith, C.T., Eds.; Kluwer Academic Publishers: Dordrecht, Netherlands, 2002; pp. 49-124.

12. Nurmi, J. The storage of logging residues for fuel. Biomass Bioenergy 1999, 17, 41-47.

13. Thörnqvist, T. Drying and storage of forest residues for energy production. Biomass 1985, 7 , 125-134.

14. Gautam, S.; Pulkki, R.; Shahi, C.; Leitch, M. Fuel quality changes in full tree logging residue during storage in roadside slash piles in Northwestern Ontario. Biomass Bioenergy 2012, 42, 43-50.

15. Nurmi, J.; Hillebrand, K. The characteristics of whole-tree fuel stocks from silvicultural cleanings and thinnings. Biomass Bioenergy 2007, 31, 381-392.

16. Nurmi, J.; Hillebrand, K. The Fuel Quality of Norway Spruce Logging Residues in Relation to Storage Logistics; Forest Research Bulletin; Finnish Forest Research Station: Kannus, Finland, 2001; Volume 223, pp. 42-46.

17. Filbakk, T.; Høibø, O.A.; Dibdiakova, J.; Nurmi, J. Modelling moisture content and dry matter loss during storage of logging residues for energy. Scand. J. For. Res. 2011, 26, 267-277.

18. Jirjis, R. Storage and drying of wood fuel. Biomass Bioenergy 1995, 9, 181-190. 
19. Lehtikangas, P. Avverkningsrester i Hyggeshögar-Avbarrning och Bränslekvalitet (Logging Residues in Piles-Needle Loss and Fuel Quality); Report No. 223; Department of Forest Products, Swedish University of Agricultural Sciences: Uppsala, Sweden, 1991; p. 44. (In Swedish)

20. Eriksson, A.; Eliasson, L.; Hansson, P.-A.; Jirjis, R. Effects of supply chain strategy on stump fuel cost: A simulation approach. Int. J. For. Res. 2014, 2014, 984395.

21. Nurmi, J. Recovery of logging residues for energy from spruce (Pices abies) dominated stands. Biomass Bioenergy 2007, 31, 375-380.

22. Peltola, S.; Kilpeläinen, H.; Asikainen, A. Recovery rates of logging residue harvesting in Norway spruce (Picea abies (L.) Karsten) dominated stands. Biomass Bioenergy 2011, 35, 1545-1551.

23. Eriksson, L.G. Mängd Trädrester Efter Trädbränsleskörd (Amount of Tree Residues Following Harvesting of Wood Fuel); Rapport No. 20; Projekt Skogskraft Vattenfall Utveckling AB: Vällingby, Sweden, 1994; p. 16. (In Swedish)

24. Brunberg, T.; Eliasson, L.; Lundström, H. Skotning av Färsk och Hyggestorkad Grot. (Forwarding of Fresh- or Dried-Stacked Logging Residues); Arbetsrapport No. 726; Skogforsk: Uppsala, Sweden, 2010; p. 18. (In Swedish)

25. Filipsson, J.; Nordén, B. Avbarrning av Skogsbränsle-Pilotstudie av Aktiv Avbarrning av Trädrester Med Skotargrip vid Lastning. (Defoliation of Logging Residues-A Pilot Study of Active Defoliation); Rapport No. 488; Skogforsk: Uppsala, Sweden, 2001; p. 17. (In Swedish)

26. Wall, A.; Hytönen, J. The long-term effects of logging residue removal on forest floor nutrient capital, foliar chemistry and growth of a Norway spruce stand. Biomass Bioenergy 2011, 35, 3328-3334.

27. Flinkman, M.; Fredriksson, H.; Thörnqvist, T. Barravfall hos Hyggesrester Som Funktion av Sommarexponeringens Torkeffekt. (Needle Litter in Heaps of Logging Residues during a Growing Period); Report No. 174; Department of Forest Products, Swedish University of Agricultural Sciences: Uppsala, Sweden, 1986; p. 24. (In Swedish)

28. Thörnqvist, T. Hyggesrester Som Råvara för Energiproduktion-Torkning, Lagring, Hantering Och Kvalitet (Logging Residues as a Feedstock for Energy Production-Drying, Storing, Handling and Grading); Report No. 152; Department of Forest Products, Swedish University of Agricultural Sciences: Uppsala, Sweden, 1984; p. 104. (In Swedish)

29. Nurmi, J.; Hillebrand, K. Storage alternatives affect fuel wood properties of Norway spruce logging residues. N. Z. J. For. Sci. 2001, 31, 289-297.

30. Solid Biofuels-Determination of Moisture Content-OVEN Dry Method-Part 2: Total Moisture-Simplified Method; European Standard EN-14774-2: 2009; Swedish Standard Institute: Stockholm, Sweden, 2009.

(C) 2015 by the authors; licensee MDPI, Basel, Switzerland. This article is an open access article distributed under the terms and conditions of the Creative Commons Attribution license (http://creativecommons.org/licenses/by/4.0/). 